\title{
STRATEGI PEMENUHAN HAK ELEKTORAL KELOMPOK MINORITAS SUKU ANAK DALAM SUB-ETNIS ORANG RIMBA OLEH KPU BATANGHARI, JAMBI, INDONESIA
}

\author{
Hertanto, Sindung Haryanto, dan Tabah Maryanah \\ Universitas Lampung, Bandar Lampung, Lampung, 35158, Indonesia \\ E-mail: hertanto.1960@fisip.unila.ac.id
}

\begin{abstract}
ABSTRAK. Hak politik elektoral atau hak untuk ikut serta memilih dalam pemilihan umum merupakan hak yang dimiliki oleh setiap orang. Faktanya hak tersebut masih sulit diperoleh terutama pada kelompok masyarakat minoritas. Tujuan kajian ini untuk mengungkap penyebab Orang Rimba tidak memiliki Kartu Tanda Penduduk Elektronik dan bagaimana strategi Komisi Pemilihan Umum Kabupaten Batanghari dalam mengupayakan terpenuhinya hak politik elektoral Orang Rimba pada Pemilihan Umum Tahun 2019. Metode penelitian yang digunakan adalah kualitatif berupa studi kasus tipe ekstrim terbanyak. Data dikumpulkan melalui focus group discussion, wawancara mendalam, dan dokumentasi. Kemudian analisis data menggunakan matriks peranan dalam kelompok. Hasil kajian menunjukkan bahwa ada tiga penyebab Orang Rimba tidak memiliki KTP-el, yaitu: cara hidup yang berpindah-pindah, keyakinan Orang Rimba, dan tidak adanya aturan khusus bagi Orang Rimba dalam pembuatan KTP-el. Strategi KPUD Batanghari untuk memenuhi hak politik elektoral Orang Rimba ada tiga, yaitu: pertama, strategi pada tahap pendataan pemilih yang dilakukan dengan cara memasukkan data Orang Rimba ke dalam formulir AC. Kedua, strategi pada tahap pemungutan suara, yaitu dengan cara menyediakan TPS khusus untuk Orang Rimba. Ketiga, strategi berkoordinasi dengan para pemangku kepentingan yakni bekerja sama dengan Disdukcapil dan Kejaksaan Negeri Batanghari dan Dirjen Disdukcapil Kemdendagri serta pemimpin Orang Rimba, yakni 'Temenggung' dan penghubung Orang Rimba dengan orang luar, yakni 'Jenang'. Selain itu juga melakukan konsultasi dengan KPU Provinsi Jambi dan KPU RI.
\end{abstract}

Kata kunci: Hak Politik Elektoral; Orang Rimba; Strategi KPU Kabupaten; Pemilu Serentak 2019

\begin{abstract}
The right to electoral politics or the right to vote in elections is a right that everyone has. In fact, these rights are still difficult to obtain, especially in minority communities. The purpose of this paper is to reveal why Orang Rimba does not have an Electronic Identity Card (Electronic ID card; KTP Elektronik) and how the Batanghari District Election Commission's strategy in seeking to fulfill Orang Rimba's electoral political rights in the 2019 General Election. The research method used is qualitative in the form of the most extreme type case studies. Data were collected by holding a focus group discussions, in-depth interviews, and documentation. Data were analyzed using a role in group matrix. The results showed that there are three causes of Orang Rimba not having an electronicID card, namely: the moving way of life, the beliefs of Orang Rimba, and the absence of special rules for Orang Rimba in the making of electronic ID card. Batanghari KPUD's strategy to fulfill Orang Rimba's electoral political rights is three, namely: first, the strategy at the voter registration stage is done by entering Orang Rimba data into the AC form. Second, the strategy at the voting stage, namely by providing a special polling station (TPS) for Orang Rimba. Third, the strategy of coordinating with stakeholders is to cooperate with the Department of Population and Civil Registry (DPCR; Disdukcapil) and Batanghari State Prosecutor and Director General of DPCR as well as the leader of Orang Rimba, namely 'temenggung'and Orang Rimba's liaison with outsiders, namely 'jenang'. In addition, it also conducts consultations with Local General Election Commission (KPUD) Jambi and National General Election Commission (KPU RI).
\end{abstract}

Key words: Electoral Political Rights; Orang Rimba; Local General Election Commission Strategy; Concurrent Election 2019

\section{PENDAHULUAN}

Hak politik merupakan Hak Asasi Manusia (HAM) yang dimiliki setiap warga negara. Negara mempunyai kewajiban untuk mengakui, menghormati dan memenuhi hak tersebut termasuk kepada kelompok-kelompok minoritas. International Covenant Civil and Political Rights (ICCPR) memberikan jaminan perlindungan khusus bagi kelompok minoritas. Faktanya di beberapa negara, hak-hak kaum minoritas tidak mendapat pengakuan dan penghormatan. Berbagai studi menunjukkan hal itu seperti misalnya di Srilangka (Ali, 2004), Ethiopia (Gizachew, 2019), Chile (Richards \& Gardner, 2013). Sebuah studi yang cukup luas di berbagai negara Amerika Latin menunjukkan hak-hak politik fundamental mengalami ancaman (Bye \& Ostebo, 2020).

Indonesia sebagai negara multikultur yang memiliki lebih dari 500 suku bangsa, juga mengalami persoalan yang kurang lebih sama terkait dengan hak-hak sosial politik indegeneos people. Berbagai studi membuktikan hal itu. Studi Wee (2002) menunjukkan bahwa suku Melayu di Riau mengalami localized, indigenized dan fragmented. Studi Robinson (2019) pada suku Sorowako dan Karongse'i/Dongi menyimpulkan bahwa pengakuan negara terhadap hak-hak masyarakat adat masih bersifat formalitas. Sementara itu studi Qodir (2014) pada suku Towani Tolotang menunjukkan bahwa suku minoritas tersebut mengalami penindasan politik dan diskriminasi. Yaacob \& Woong, (2007), 
mengidentifikasi bahwa perlakuan dan kebijakan pemerintah dan korporasi mengakibatkan resistensi di kalangan indegeneous people.

Pemenuhan hak politik kelompok minoritas dalam konteks pelaksanaan pemilu di Indonesia merupakan salah satu persoalan pelik di antara banyak persoalan lain. Sejumlah studi menunjukkan bahwa persoalan pemilu di Indonesia memiliki spektrum yang cukup luas. Sejumlah persoalan tersebut antara lain: broker politik dari penyelenggara pemilu (Pratitaswari \& Wardani, 2020), korupsi politik (Riwanto, 2015), klan politik (Riswandi, Nurdin, \& Alamsyah, 2019), politik uang (Dewi, 2015; Lukmajati, 2016), persepsi negatif pemilih terhadap partai politik dan rendahnya kepercayaan terhadap pemerintah (Hermawan, 2014; Merly, 2015), rendahnya loyalitas pemilih terhadap partai politik (Yustiningrum \& Ichwanudin, 2015), verifikasi partai politik peserta pemilu, DPT, pemberian suara dan pemungutan suara, tertunda dan berubah-ubahnya penetapan hasil pemilu (Romli, 2005), pragmatisme politik (Aminuddin \& Ramadlan, 2015), veto player elit partai politik (Budi, 2013), rendahnya keterwakilan perempuan (Zainal, 2015; Rahman, Harsono \& Dewi, 2017), peran Bawaslu yang belum substansial (Siddha \& Witjaksono, 2018), pemenuhan hak pilih kaum disabilitas (Zainal, Iqbal, dan Razak, 2018), rendahnya pengetahuan pemilih pemula (Rachmiatie, Sidik, \& Kamil, 2005), meningkatnya golput dan swing voter (Martinus, 2013), patronase (Firmadi \& Purwaningsih, 2016; Harjanto, 2012) dan klientelisme politik (Firmadi \& Purwaningsih, 2016). Berbagai persoalan pemilu tersebut sangat mempengaruhi kualitas demokrasi. Jika dipetakan berbagai persoalan pemilu tersebut mencakup semua tahapan pemilu mulai dari tahap persiapan (prapemilu) hingga tahap pascapemilu. Secara lebih terperinci, peta persoalan tersebut tersaji pada tabel 1.

Tabel 1. Peta Persoalan Pemilu di Indonesia

\begin{tabular}{|c|c|c|}
\hline No. & Aktor utama & Jenis Persoalan \\
\hline 1 & $\begin{array}{l}\text { Penyelenggara } \\
\text { pemilu (KPU, } \\
\text { Bawaslu) }\end{array}$ & $\begin{array}{l}\text { Administrasi pemilu (verifikasi partai } \\
\text { politik peserta pemilu, DPT, berubah- } \\
\text { ubahnya penetapan hasil pemilu), broker } \\
\text { politik, peran Bawaslu yang masih } \\
\text { formal, pemenuhan hak kaum disabilitas/ } \\
\text { kelompok minoritas. }\end{array}$ \\
\hline 2 & Partai Politik (elit) & $\begin{array}{l}\text { Veto player, patronase, klientelisme, } \\
\text { pragmatisme politik, rendahnya } \\
\text { keterwakilan perempuan. }\end{array}$ \\
\hline 3 & $\begin{array}{l}\text { Kandidat calon } \\
\text { (eksekutif/legislatif) }\end{array}$ & $\begin{array}{l}\text { Korupsi politik, klan politik, politik } \\
\text { uang. }\end{array}$ \\
\hline 4 & Pemilih & $\begin{array}{l}\text { Persepsi negatif pemilih terhadap } \\
\text { partai politik, rendahnya } \\
\text { kepercayaan terhadap pemerintah, } \\
\text { rendahnya loyalitas pemilih terhadap } \\
\text { partai politik, rendahnya pengetahuan } \\
\text { pemilih pemula, meningkatnya golput } \\
\text { dan swing voter. }\end{array}$ \\
\hline
\end{tabular}

Sumber: Diolah dari data sekunder, 2020
Tabel 1 menunjukkan bahwa persoalan pemenuhan hak politik kaum minoritas merupakan salah satu bagian persoalan dari kompleksitas problem pemilu di Indonesia. Masyarakat suku-suku terasing di Indonesia sebagai kelompok minoritas hingga saat ini banyak yang belum terpenuhi hak politiknya dalam pemilu karena pada umumnya tidak memiliki KTP elektronik sebagai basis pendaftaran pemilih. Persoalan ini juga dialami oleh Suku Anak Dalam Sub-etnis Orang Rimba, selanjutnya ditulis Orang Rimba, di Provinsi Jambi pada Pemilu 2019. Menurut Prastiwi (2018), kendala pemenuhan hak politik Orang Rimba tersebut karena budaya nomaden yang menyebabkan masyarakat tidak memiliki Kartu Tanda Penduduk elektronik (KTP-el).

Hak politik elektoral pada suku-suku/ kelompok minoritas di Indonesia juga masih menjadi problem krusial. Studi Syaputra \& Nasution (2019) menunjukkan bahwa hak-hak politik kelompok masyarakat minoritas penganut kepercayaan mengalami ketidakadilan dan diskriminasi. Studi Zulkarnain et al. (2018) mengidentifikasi pembungkaman suara politik masyarakat Suku Mapur Lom di Bangka Belitung. Masyarakat MoroMoro yang tinggal di Register 45 Mesuji, Lampung juga mengalami persoalan dalam kaitannya dengan pemenuhan hak politik dalam pemilu (Rasyidi, 2017).

Hak politik elektoral Suku Anak Dalam Subetnis Orang Rimba, di Provinsi Jambi pada Pemilu 2019 tidak terpenuhi karena tidak memiliki Kartu Tanda Penduduk elektronik (KTP-el) (Prastiwi, 2018). Orang Rimba tersebar di empat kabupaten di Provinsi Jambi. Secara terperinci sebaran Orang Rimba yang kehilangan hak politik elektoralnya adalah sebagai berikut.

Tabel 2. Jumlah Penduduk Suku Anak Dalam yang tidak masuk di Daftar Pemilih Tetap (DPT) berdasarkan Jenis Kelamin pada Pemilu 2019

\begin{tabular}{llccc}
\hline \multirow{2}{*}{ No. } & \multirow{2}{*}{ Kabupaten } & \multicolumn{2}{c}{ Jenis Kelamin } & \multirow{2}{*}{ Jml } \\
\cline { 3 - 4 } & & $\mathbf{L}$ & $\mathbf{P}$ & \\
\hline 1 & Batanghari & 358 & 230 & 588 \\
2 & Tebo & - & - & - \\
3 & Sarolangun & 45 & 52 & 97 \\
4 & Merangin & 27 & 24 & 51 \\
\hline & Jumlah & 403 & 282 & 736 \\
\hline & & &
\end{tabular}

Sumber: KPU Provinsi Jambi, 2019

Hilangnya hak elektoral kelompok minoritas seperti yang terjadi pada Orang Rimba menunjukkan bahwa negara belum sepenuhnya dapat menjamin hak-hak sosial politik kepada seluruh warga negaranya. Dalam konteks kehidupan demokrasi, hilangnya hak-hak politik sebagian warga negaranya dapat menurunkan partisipasi politik masyarakat. Menurut (Budiardjo, 2008), rendahnya partisipasi masyarakat 
darah bagi demokrasi (Franklin, 2002). Semakin tinggi tingkat dan intensitas partisipasi politik maka akan semakin tinggi pula kualitas demokrasi. Sebaliknya, semakin rendah bentuk dan intensitas partisipasi politik warga maka akan semakin rendah pula kualitas demokrasi (Budiardjo, 2008).

Negara berkewajiban untuk memenuhi hak politik elektoral. Tidak saja karena perkembangan HAM generasi keempat yang mewajibkan negara untuk memenuhi HAM, terpenuhinya HAM melainkan juga untuk tujuan menciptakan demokrasi yang kuat. Terpenuhinya hak elektoral setiap warga negara merefleksikan budaya politik yang sehat dan menjadi faktor pendorong legitimasi pemerintahan.

Sebaliknya, tidak terpenuhinya hak politik elektoral menyebabkan ada kelompok warga yang tereksklusi. Jika masih ada warga yang terekslusi maka demokrasi tidaklah komplit (Lawoti, 2007). Artinya pencapaian demokrasi tidak akan ter-wujud secara optimal. Begitu pentingnya makna terpenuhinya hak pilih elektoral warga bagiHAM dan demokrasi. Dengan demikian, terpenuhinya hak pilih elektoral memiliki dimensi HAM maupun dimensi demokrasi sekaligus.

\section{Strategi KPU dalam Memenuhi Hak Warga}

Penanggung jawab utama penyelenggaraan pemilu di Indonesia berada di tangan KPU. Sukses atau gagalnya pemilu akan sangat tergantung bagaimana kinerja KPU dan jajarannya dalam setiap tahapan pemilu. Apakah pemilu berjalan lancar atau tidak akan ditentukan oleh tindakan KPU. Apakah pemilu berlangsung secara jujur dan adil juga lebih banyak dipengaruhi oleh kerja-kerja KPU. KPU sebagai penyelenggara memiliki enam fungsi utama, yaitu:

1. Menentukan siapa warga negara yang berhak memilih. Hak warga negara dewasa untuk berpartisipasi dalam pemilihan adalah salah satu landasan demokrasi. KPU juga harus memastikan bahwa hanya orang yang berhak memilihlah yang dapat memberikan legitimasi pada proses pemilihan.

2. Menerima dan memvalidasi calon peserta pemilu, baik peserta partai politik maupun peserta perorangan. Hak untuk mencalonkan diri dalam pemilu adalah hak politik yang fundamental. Terkait dengan fungsi kedua ini, KPU juga harus memastikan bahwa semua kontestan telah mengikuti peraturan agar dapat memberikan legitimasi pada pemilu.

3. Menyelenggarakan pemungutan suara. Kemampuan KPU terkait tahapan ini sangat penting. Pemilih dapat memberikan suara dengan aman merupakan inti dari suatu pemilihan.

4. Menghitung suara agar hasil pemilu mencerminkan kemauan pemilih.
5. Tabulasi suara sesuai dengan sistem pemilu sehingga dapat diketahui pemenangnya.

6. Menjalankan organisasi yang kredibel agar legitimasi pemilu tidak terganggu oleh tindakan penyelenggara pemilu (Catt, 2014).

Begitu pentingnya peranan KPU dalam pemilu dan begitu menentukannya strategi yang dipilih oleh KPU dalam menjalankan fungsi utamanya. Dalam menjalankan fungsi inti pertama, yakni menentukan siapa saja warga negara yang berhak memilih, tugas KPU dapat diperluas menjadi:

1. Mengidentifikasi dan mendaftarkan pemilih;

2. Mengidentifikasi dan mendaftarkan pemilih yang tinggal di negara lain yang masih berhak memilih;

3. Mengembangkan dan memelihara daftar pemilihan nasional.

Proses pemilu secara umum dikelompokkan ke dalam tiga tahap. Tahap pertama adalah sebelum pemungutan suara. Tahap kedua adalah pemungutan suara. Tahap ketiga adalah setelah pemungutan suara. Ketiga tahapan tersebut sangat menentukan berhasil tidaknya penyelenggaraan pemilu. Tahapan penting terkait dengan pemenuhan hak elektoral warga adalah pada pendataan pemilih dan pemungutan suara. Tahap pendataan pemilih menentukan siapa saja yang akan masuk ke dalam daftar orang yang memiliki hak pilih. Daftar pemilih akan menentukan siapa yang pada saat pemungutan suara dapat memberikan suara.

Berdasarkan fungsi utama dan perluasan fungsi utama, KPU sangat menentukan apakah seorang warga dapat masuk ke dalam daftar pemilih atau tidak. Begitu juga saat pemungutan suara, apakah seorang warga dapat memberikan suara atau tidak sangat terkait dengan kerja KPU. Ini juga berarti bahwa terpenuhi atau tidaknya hak politik elektoral warga sangat terkait dengan strategi KPU dalam menjalankan fungsinya.

Selain KPU sebagai penanggung jawab utama, proses penyelenggaraan pemilu melibatkan banyak pemangku kepentingan (stakeholder), baik individu, kelompok, maupun organisasi. Ada dua jenis pemangkukepentingandalam pemilu, yaknipemangku kepentingan utama dan pemangku kepentingan sekunder (Catt, 2014). Pemangku kepentingan utama akan memengaruhi kegiatan, kebijakan, maupun praktik KPU secara langsung. Sedangkan hubungan pemangku kepentingan sekunder dengan KPU bersifat lebih longgar. Ada 11 pemangku kepentingan utama dalam penyelenggaraan pemilu, yaitu:

1) partai politik dan para kandidat;

2) Staf penyelenggara, baik staf KPU maupun panitia ad hoc;

3) cabang eksekutif pemerintah, yakni pemerintah daerah; 
kebun karet atau kebun sawit. Berbeda sekali dengan Orang Rimba yang masih tinggal di dalam hutan, Orang Rimba yang sudah menetap biasanya tinggal di dusun dengan kebudayaan yang berbeda dengan yang masih tinggal di hutan.

Orang Rimba yang tinggal di hutan maupun di dusun memiliki hak elektoral yang sama. Jumlah Orang Rimba di Provinsi Jambi pada Pemilu 2019 adalah 5.235, tersebar di empat kabupaten. Jumlah terbanyak ada di Kabupaten Soralangun, terbanyak berikutnya di Kabupaten Merangin, Tebo, Batanghari dan Bungo. Rincian jumlah dan sebaran Orang Rimba dapat dilihat pada Tabel 3 berikut ini.

Tabel 3. Sebaran Suku Anak Dalam di Provinsi Jambi

\begin{tabular}{clcc}
\hline No. & Kabupaten & Jumlah Jiwa & Persentase \\
\hline 1. & Sarolangun & 2.228 & 42,56 \\
2. & Merangin & 1.276 & 24,37 \\
3. & Tebo & 707 & 13,51 \\
4. & Batanghari & 629 & 12,01 \\
5. & Bungo & 395 & 6,86 \\
\hline & Jumlah & 5.235 & 100 \\
\hline
\end{tabular}

Sumber: Juaini, 2020

\section{Penyebab Orang Rimba Tidak Memiliki KTP Elektronik}

Sebagaimana telah disebutkan sebelumnya bahwa salah satu syarat untuk memilih adalah memiliki KTP-el. Sayangnya, 588 Orang Rimba tidak memiliki KTP-el sehingga kehilangan hak politik elektoralnya pada Pemilu Serentak 2019. Orang Rimba tidak dapat memiliki KTPel disebabkan oleh tiga hal, yaitu: cara hidup yang berpindah-pindah, keyakinan Orang Rimba, dan tidak adanya aturan khusus bagi Orang Rimba dalam pembuatan KTP-el. Pertama, cara hidup Orang Rimba yang berpindah-pindah dan tinggal di hutan karena berbagai alasan, serta karena keyakinan mereka. Cara hidup berburu dan meramu membuat mereka harus berpindah tempat jika daerah sekitar tempat tinggal tidak lagi tersedia makanan. Jika pun sebagian dari mereka berladang, teknik meladang tradisional mengharuskan mereka berpindah tempat jika tanahnya sudah tidak subur. Pupuk kandang tidak mereka miliki karena mereka tidak memiliki ternak. Pupuk buatan yang berada di luar hutan juga tidak dapat mereka akses. Satu-satunya jalan adalah berpindah tempat tinggal jika ladang mereka sudah tidak subur lagi. Tradisi melangun juga menjadi alasan lain bagi Orang Rimba untuk berpindah tempat tinggal jika ada anggota keluarga yang meninggal. Orang Rimba juga berpindah tempat tinggal untuk menghindari musuh. Alasan terakhir ini semakin jarang digunakan. Cara hidup berpindah-pindah ini membuat Orang Rimba sulit mendapatkan KTP-el.
Syarat untuk mendapatkan KTP-el menurut Pasal 24 Peraturan Menteri Dalam Negeri Nomor 11 Tahun 2010 adalah memiliki Surat Keterangan Komunitas Terpencil (SKTK). Untuk mendapatkan SKTK diperlukan Surat Pernyataan Pengakuan Kepala Suku/Adat. Selanjutnya Pasal 25 menentukan bahwa untuk mendapatkan KTP komunitas terpencil harus telah berdomisili tetap dan telah mendapatkan SKTK. Ketentuan inilah yang menjadi penghambat Orang Rimba untuk mendapatkan KTP-el, sebagaimana ditegaskan oleh Abdul Kadir, Ketua KPU Kabupaten Batanghari, sebagai berikut:

Mereka nomaden (berpindah-pindah) dan tidak menetap minimal selama 3 (tiga) bulan, (syarat dapat diberikan Tanda Komunitas), sehingga pada Pemilu 2019 dari 588 pemilih Orang Rimba ini dan tersebar di dua kecamatan akhirnya tidak bisa memiliki hak Pilih pada Pemilu Serentak 2019 karena tidak punya KTP Elektronik (Wawancara, 13 Juli 2020).

Kedua, keyakinan Orang Rimba. Selain karena cara hidupnya yang berpindah-pindah, Orang Rimba juga memiliki keyakinan unik terkait dengan kematian. Selain upacara melangun yang membuat mereka harus berpindah tempat tinggal, Orang Rimba juga memiliki keyakinan untuk tidak menyebut nama orang yang sudah meninggal. Hal ini akan menyulitkan pendataan penduduk karena dalam pendataan penduduk juga mesti mencantumkan nama ibu kandung dan nama ayah kandung. Sementara bagi Orang Rimba menyebut nama orang yang sudah meninggal adalah pantangan. Dalam proses perekaman KTP-el juga ada persoalan. Orang Rimba memiliki aturan larangan bagi pihak luar untuk memfoto perempuan Rimba. Jika pun ada Orang Rimba yang sudah berhasil direkam dan mendapatkan KTP, jika ada anggota keluarga yang meninggal maka KTP-el dan Kartu Keluarga yang memuat nama orang yang meninggal tersebut akan dibakar. Hal ini akan menyulitkan anggota keluarga yang masih hidup untuk mendapatkan KTP-el karena Kartu Keluarga merupakan salah satu syarat untuk mendapatkan KTP-el.

Ketiga, tidak ada aturan khusus bagi Orang Rimba dalam pembuatan KTP-el. Cara hidup Orang Rimba berbeda dengan warga lain yang sudah menetap. Cara hidup Orang Rimba membuat Orang Rimba tidak dapat memenuhi persyaratan untuk mendapatkan KTP-el. Cara hidup yang berpindahpindah di hutan oleh pemerintah Indonesia dan KPU dihadapi dengan cara yang sama dengan cara hidup menetap. Syarat-syarat untuk mendapatkan KTP-el bagi Orang Rimba disamakan dengan orang yang berbudaya hidup menetap. Hal ini juga menjadi penyebab Orang Rimba tidak mendapatkan KPT-el. 
suara (TPS) khusus untuk Orang Rimba pada Pemilu 2019. TPS tersebut digabungkan terlebih dahulu ke desa terdekat sehingga apabila Suku Anak Dalam (SAD) telah memiliki KTP-el maka TPS khusus tetap ada. Berikut keterangan dari Ketua KPU Batanghari:

Mereka ini kan kita ketahui juga sulit untuk beradaptasi langsung dengan masyarakat secara umum sehingga kita sediakan TPS khusus bagi mereka awalnya. Namun pada saat penetapan $D P S$, ini kan tidak mungkin ada TPS yang kosong karena mereka tidak ada yang masuk dalam pendataan karena terkait dengan KTP-el tadi. Maka TPS ini kita Dorong ke tempat desadesa setempat tapi lokasinya dipindah dan diisi oleh masyarakat biasa, tapi suatu nanti mereka sudah memiliki KTP-el maka ini bisa kita geser kembali TPS tersebut. (Abdul Kadir, Focus Group Discussion, 7 Juli 2020)

Itulah strategi yang dijalankan oleh KPU Batang hari dalam upaya memenuhi hak politik elektoral Orang Rimba. KPU telah mempertimbangkan kondisi Orang Rimba yang khas, karena Orang Rimba tinggal di hutan dan jarang berinteraksi dengan orang di luar hutan, apalagi yang memang jarang keluar hutan sehingga sulit beradaptasi cara hidup di luar hutan. Meskipun, pada saat pemungutan suara 588 Orang Rimba tetap tidak dapat memilih. Strategi KPU ini dibenarkan oleh Badan Pengawas Pemilu (Bawaslu) bahwa KPU Batanghari telah berupaya memenuhi hak politik elektoral Orang Rimba pada Pemilu 2019 namun terkendala oleh undang-undang dan peraturan KPU RI (Indra Tritusian, Focus Group Discussion, 7 Juli 2020). Strategi demikian juga menunjukkan bahwa KPU Batanghari melakukan manajemen resiko pemilu (Sakbani, 2020) untuk melindungi hak pilih elektoral Orang Rimba.

\section{Koordinasi KPU dengan Pemangku Kepentingan}

Kewenangan penyelenggara pemilu (electoral managementbody-EMB) ditiapnegara berbeda-beda. Ada negara yang penyelenggara pemilunya diberi wewenang untuk membuat daftar penduduk, seperti Kosta Rika dan Republik Dominika. Penyelenggara pemilu di Bangladesh dan Guyana tidak hanya menerbitkan kartu pendaftaran pemilih, namun sekaligus memiliki tanggung jawab menerbitkan dokumen identitas nasional, yang menjadi syarat untuk masuk daftar pemilih. Penyelenggara pemilu di Kolombia, Hongaria, Belanda, Rumania dan Swedia pendaftaran pemilih dilakukan oleh otoritas di luar penyelenggara pemilu. Sedangkan di Spanyol, Kantor Sensus Pemilihan Institut Statistik Nasional (Electoral Census Office of the National Institute of Statistics) adalah badan yang bertanggung jawab. Moldova dan Korea Selatan berbeda lagi, otoritas lokal mempersiapkan daftar pemilih untuk penyelenggara pemilu independen (Catt, 2014). KPU di Indonesia hanya diberi kewenangan untuk membuat daftar pemilih sedangkan KTP-el yang menjadi syarat untuk memilih hanya bisa dikeluarkan oleh Disdukcapil.

Guna memenuhi hak pilih elektoral Orang Rimba, KPU Batanghari mesti berkoordinasi dengan para pemangku kepentingan terkait. Agar dapat mendata Orang Rimba, KPU berkoordinasi dengan 'Temenggung', yang merupakan pinpinan Orang Rimba atau 'Jenang' (Abdul Kadir, Focus Group Discussion, 7 Juli 2020), sebagai penghubung antara Orang Rimba dengan orang luar. Kedua aktor inilah yang mempermudah kerja KPU karena cara hidup Orang Rimba yang berpindah-pindah dan tempat tinggal Orang Rimba yang berpencar-pencar di dalam hutan menjadi beberapa kelompok. Selain itu juga karena pandangan Orang Rimba terhadap orang luar yang cenderung negatif, misalnya orang luar membawa penyakit. Orang Rimba juga sangat protektif terhadap perempuan dan anak-anak sehingga tidak mudah bagi orang luar untuk bertemu atau masuk ke wilayah tempat tinggal Orang Rimba.

Terkait dengan KTP-el, KPU berkordinasi dengan Dinas Kependudukan dan Catatan Sipil (Disdukcapil). KPU mengundang Disdukcapil dan intansi terkait lain untuk pemuktahiran data pemilih. Salah satu pembahasan penting yaitu terkait Orang Rimba yang terdata tapi tidak memiliki KTP-el. KPU Batanghari melakukan konsultasi ke KPU Provinsi Jambi dalam kaitannya dengan Orang Rimba di Kabupaten Batanghari yang terdata tapi tidak bisa masuk dalam DPT karena tidak punya KTP-el. KPU Batanghari juga menyurati KPU RI melalui KPU Provinsi meminta agar Orang Rimba diberikan kekhususan dalam pemilu. Kekhususan yang dimaksud adalah Orang Rimba memberikan suara dengan Sistem Noken ${ }^{l}$ seperti masyarakat adat di Papua. Usulan affirmative action tersebut diajukan karena Orang Rimba bukan hanya di Kabupaten Batanghari saja, tetapi tersebar di tiga kabupaten lainnya, yakni Kabupaten Tebo, Sorolangun, dan Merangin. Affirmative action menjadi keniscayaan sebagai salah satu cara untuk memenuhi hak politik warga, sebagaimana dilakukan untuk memenuhi hak perempuan dalam politik (Rahmatunnisa, 2016)

\footnotetext{
1 Sistem Noken adalah tata cara pemilihan di mana pilihan seluruh anggota suku diwakilkan kepala suku masing-masing atau aklamasi. Noken, tas khusus etnis Papua, juga dapat berfungsi sebagai pengganti kotak suara. Pada Pemilu 2019 ada 12 kabupaten di kawasan Pegunungan Tengah Papua menggunakan Sistem Noken. Sedangkan 15 kabupaten dan kota yang berada di pantai tidak menggunakan Sistem Noken. https:/www.cnnindonesia.com/nasional/20190405195952-32-383808/sistem-pemilu-noken -akan-digunakan-12-kabupaten-di-papua. Diakses pada tanggal 25 November 2020, 10.00 WIB.
} 
tersebut pada gilirannya dapat mempengaruhi legitimasi pemerintahan yang berkuasa.

Berbagai studi terdahulu menunjukkan terdapat beberapa faktor yang menyebabkan hak politik elektoral masyarakat suku/kelompok minoritas tidak terpenuhi. Berbagai faktor tersebut antara lain: konflik agraria (Rasyidi, 2017), pembangunan ekonomi yang berorientasi kapitalis (Zulkarnain et al., 2018), dan masyarakat hanya menganut kepercayaan lokal tanpa memeluk salah satu dari keenam agama resmi (Syaputra \& Nasution, 2019). Ketiga faktor tersebut bermuara pada problem yang sama yakni masyarakat tidak mempunyai akses untuk memiliki KTP elektronik sebagai basis pencatatan DPT.

Penelitian ini bertujuan untuk mengetahui penyebab Orang Rimba tidak memiliki KTP-el dan bagaimana strategi Komisi Pemilihan Umum Kabupaten Batanghari dalam mengupayakan terpenuhinya hak politik elektoral Orang Rimba pada Pemilihan Umum Tahun 2019.

Penelitian ini memiliki kebaruan (novelty) berupa upaya-upaya KPU, baik secara substantif maupun secara teknis, dalam mengambil kebijakan afirmatif terhadap kelompok minoritas sebagai implementasi ICPPR. Terutama terkait dengan persoalan KTP-el kelompok adat karena cara hidup dan kebudayaannya.

\section{METODE}

Metode penelitian yang digunakan adalah kualitatif, berupa studi kasus tipe ekstrim terbanyak (Yin, 1994). Metode ini dipilih untuk mendapatkan informasi mendalam mengenai bagaimana strategi KPU Batanghari memenuhi hak politik elektoral Orang Rimba. Data dikumpulkan dengan menggunakan metode wawancara mendalam, focus group discussion (FGD) dan dokumentasi. Sebanyak 13 informan berpartisipasi dalam wawancara mendalam. Sementara itu FGD diikuti oleh 6 peserta yang berasal dari berbagai institusi di Provinsi Jambi. Setelah dilakukan wawancara pendahuluan, peneliti kemudian menghubungi dan mewawancarai calon-calon informan yang terdiri dari komisioner KPU Provinsi Jambi, komisioner KPU Kabupaten Batanghari, perwakilan sekretariat KPU Kabupaten Batanghari, perwakilan dari Dinas Kependudukan dan Catatan Sipil Kabupaten Batanghari, komisioner Bawaslu Kabupaten Batanghari, Badan Ad Hoc KPU Kabupaten Batanghari, Tim Relawan Demokrasi Kabupaten Batanghari, tokoh masyarakat Orang Rimba, Perwakilan Partai Politik, perwakilan Ormas/ LSM (KKI Warsi dan kopipede), media massa, dan perwakilan akademisi. Proses wawancara dilakukan mulai Bulan Juli 2020 hingga Bulan September 2020. Pelaksanaan $F G D$ dilakukan pada Bulan
Oktober 2020. Data yang terkumpul dianalisis dengan analisis matrik peranan dalam kelompok (Miles \& Huberman, 1992:191).

\section{HASIL DAN PEMBAHASAN}

\section{Pemilu, Hak Warga dalam Pemilu, dan Demokrasi}

Tiap warga memiliki hak asasi manusia (HAM) yang dijamin oleh undang-undang. Tiap warga memiliki hak sipil, hak politik, hak sosial (Stoke, 2017). Hak sipil adalah hak yang melindungi keamanan dan privasi, termasuk di dalamnya hak untuk mengakses keadilan dan hukum yang representatif; hak untuk membuat kontrak dan memiliki properti pribadi; hak untuk bebas bersuara, termasuk bebas berbicara, beragama, dan lain-lain. Hak politik merupakan hak terkait dengan partisipasi di ruang publik dan proses politik. Termasuk di dalamnya hak untuk memilih dan dipilih dalam pemilu, membentuk organisasi dan partai politik, serta hak untuk berbeda pendapat dan melakukan protes. Sedangkan hak sosial meliputi hak untuk hidup sejahtera. Termasuk di dalamnya hak untuk mendapatkan layanan kesehatan, kesempatan untuk mendapatkan pendidikan dan pekerjaan. Implementasi dari hak sipil dan politik ini berbeda masing-masing negara. Menurut Hasan dan Sari (2005), secara empiris terdapat beberapa indikator penjelastentangkeberadaanhaksipildan politikdalam suatu negara, di antaranya (1) terdapatnya partisipasi politik yang tinggi, baik secara kualitas maupun kuantitas; (2) terdapatnya kebebasan individu untuk berbeda pendapat; (3) kebebasan pers dan hak untuk memperoleh informasi; (4) terjaminnya hak untuk berorganisasi dan menyampaikan pendapat; (5) hak untuk beroposisi; dan (6) terdapatnya penegakan hak petisi, berdemonstrasi.

Hak pilih elektoral merupakan hak warga yang memenuhi syarat undang-undang untuk memberikan suara (voting) pada pemilihan umum (pemilu). Pemilu merupakan semua jenis pemilihan, yakni pemilihan anggota DPR, DPRD, dan DPD yang lazim disebut pemilihan legislatif (pileg); pemilihan presiden (pilpres), dan juga pemilihan gubernur dan wakil gubernur, pemilihan bupati dan wakil bupati, serta pemilihan wali kota dan wakil wali kota yang sering disebut pemilihan kepala daerah atau pilkada. Dengan demikian, pemilu meliputi semua jenis pemilihan elit politik tersebut.

Hak politik elektoral merupakan salah satu bentuk partisipasi politik konvensional yang sangat penting bagi demokrasi. Sebuah negara disebut demokrasi jika sekurang-kurangnya ada keterlibatan warga dalam politik. Salah satu bentuk keterlibatan warga yang penting ialah memberikan suara dalam pemilu. Partisipasi sendiri dalam politik merupakan 
4) badan legislative, yakni DPRD;

5) badan penyelesaian sengketa pemilu, baik Mahkamah Konstitusi, Mahkamah Agung beserta jajarannya, maupun dewan kehormatan penyelenggara pemilu (DKPP) yang menyelesaikan pelanggaran kode etik anggota KPU dan/atau badan pengawas pemilu (Bawaslu);

6) sistem peradilan;

7) pemantau pemilu dan warga negara serta pemantau pemilu internasional;

8) media;

9) pemilih: pemilih dan calon pemilih;

10) Organisasi masyarakat sipil (Civil Society Organisation); dan

11) komunitas donor dan lembaga bantuan pemilu.

Proses pendataan pemilih akan sangat terkait dengan pemerintah daerah karena salah satu syarat untukmenjadi pemilih adalahmemiliki kartuidentitas penduduk, yakni kartu tanda penduduk elektronik (KTP-el) dan kartu keluarga (KK). Sayangnya wewenang penerbitan KTP-el dan KK bukan wewenang KPU. Wewenang untuk menerbitkan KTP-el dan KK berada pada Dinas Kependudukan dan Pencatatan Sipil (Disdukcapil). Ini berarti bahwa untuk memenuhi hak pilih elektoral Orang Rimba, KPU mesti berkoordinasi dengan Disdukcapil. Tanpa kerjasama dengan Disdukcapil sulit bagi KPU untuk memenuhi hak politik elektoral Orang Rimba.

KPU sebagai penyelenggara pemilu juga berkewajiban memberikan layanan kepada pemilih (Catt, 2014). Mengingat banyaknya tahapan pemilu dan banyaknya tugas KPU atas nama pemilih, KPU perlu memberikan informasi kepada para pemilih tentang kegiatan dan program-program KPU, tanpa kecuali kepada Orang Rimba, meskipun sebagian Orang Rimba tinggal di hutan. Dengan demikian KPU perlu melakukan strategi tertentu agar dapat memenuhi hak pilih elektoral Orang Rimba pada Pemilu 2019.

\section{Orang Rimba dalam Pemilu Serentak 2019}

Orang Rimba merupakan salah satu sub-etnis dari kelompok minoritas etnis yang disebut sebagai Suku Anak Dalam. Suku Anak Dalam terdiri dari sub-etnis Talang Mamak, sub-etnis Batin Sembilan, dan sub-etnis Orang Rimba. Orang Rimba bermukim kawasan Taman Nasional Bukit Dua Belas (TNBD), Taman Nasional Bukit Tiga Puluh (TNBT), Taman Nasional Kerinci Seblat (TNKS), serta hutan sekunder dan perkebunan kelapa sawit sepanjang jalur lintas Sumatera hingga Sumatera Selatan (Juaini, 2020). Menteri Kehutanan menetapkan kawasan hutan Bukit Duabelas sebagai kawasan Cagar Biosfer melalui Surat Keputusan (SK) nomor: 46/Kpts-II/1987 seluas 29.485 hektar pada tanggal 12
Februari 1987. Kemudian status kawasan meningkat menjadi taman nasional berdasarkan Surat Keputusan Menteri Kehutanan: SK.4196/Menhut-II/2014, seluas 54.780,4 hektar pada tanggal 10 Juni 2014. Kawasan taman nasional terletak di Kabupaten Tebo, Kabupaten Batanghari, dan Kabupaten Sarolangun, Provinsi Jambi (Mulyani \& Parapat, 2018:19-23), dan (KKI WARSI, 2019).

Sebagian besar sub-etnis Talang Mamak dan sub-etnis Batin Sembilan sudah tinggal menetap. Sedangkan sebagian besar sub-etnis Orang Rimba masih hidup melangun atau berpindah-pindah tempat hidup secara berkelompok di hulu-hulu sungai di dalam hutan (KKI WARSI, 2020). Oleh karenanya sub-etnis Orang Rimba sering disebut 'masyarakat terasing'. Jumlah yang sedikit dan cara hidup yang berpindah-pindah menyebabkan Orang Rimba menjadi kelompok minoritas, baik secara etnis maupun kebudayaan. Kebudayaan dalam tulisan ini adalah serangkaian pengetahuan, nilai, norma, dan aturan yang dipakai oleh manusia untuk memahami serta menginterpretasikan lingkungannya dan dipakai untuk mendorong terwujudnya tingkah laku (Suparlan, 2011). Dengan demikian, kebudayaan memiliki pengertian yang luas, menyangkut segala aspek kehidupan Orang Rimba.

Orang Rimba dapat dibagi ke dalam tiga kategori, yakni: 1) Orang Rimba yang masih tinggal di hutan dan berpindah-pindah tempat tinggal. Orang Rimba kategori pertama ini tidak banyak berinteraksi dengan orang di luar hutan. Mereka hanya menggunakan teknologi sederhana; 2) Orang Rimba yang masih tinggal di hutan tapi sudah banyak berinteraksi dengan orang di luar hutan, serta menggunakan teknologi modern seperti kendaraan bermotor; 3) Orang Rimba yang sudah menetap di dusun dan hidup sebagaimana orang dusun. Ketiga kategori ini memiliki kebudayaan yang berbeda dan dalam aspek-aspek kebudayaan tertentu saling menegasikan.

Orang Rimba yang masih tinggal di hutan memandang dirinya sebagai: 1) orang yang tinggal di dalam hutan; 2) memiliki pola hidup yang sesuai dengan lingkungan yang ada di hutan, seperti berpakaian hanya menggunakan cawot (cawat) bagi laki-laki dan memakai kemben bagi perempuan; 3) hidup berpindah-pindah, tidak menetap; 4) percaya pada agama nenek moyang; 5) mata pencaharian hidup sesuai dengan lingkungan hutan seperti berburu, meramu, dan berladang; 6) memakan semua makanan yang tersedia di dalam hutan (Prasetijo, 2011:92-93). Sedangkan Orang Rimba yang sudah banyak berinteraksi dengan orang di luar hutan lebih sering menggunakan pakaian, terutama jika bertemu dengan orang dusun. Menggunakan teknologi seperti kendaraan bermotor, dan sebagian sudah memiliki 
Ternyata tidak terpenuhinya hak elektoral dalam Pemilu Serentak 2009 karena tidak meiliki KTP-el tidak hanya dialami oleh Orang Rimba. Kelompok minoritas adat di tempat lain di wilayah Indonesia juga mengalami hal yang sama. Berdasarkan hasil pemantauan Tim Pemantauan Pileg dan Pilpres 2019, Komisi Nasional Hak Asasi Manusia (Komnas HAM), etnis Kajang di Sulawesi Selatan dan komunitas adat di Kabupaten Kotawaringin Barat dan Lamandau, Provinsi Kalimantan Tengah serta etnis Badui di Kabupaten Lebak, Provinsi Banten juga tidak terpenuhi hak pilih elektoralnya karena tidak memiliki KTP-el (Rahman, Harsono \& Dewi, 2017); (Firmansyah, 2019).

Hal ini mengindikasikan bahwa persoalan tidak memiliki KTP-el yang menghambat terpenuhinya hak pilih elektoral dalam Pemilu Serentak 2019 tidak hanya persoalan lokal kabupaten Batanghari, namun merupakan masalah di tiga kabupaten lain di provinsi Jambi, yakni Kabupaten Tebo, Sarolangun, dan Merangin. Juga menjadi persoalan yang bersifat nasional karena terjadi di beberapa kabupaten dan kota di Indonesia.

\section{Strategi KPU Kabupaten Batanghari Memenuhi Hak Politik Elektoral Orang Rimba}

Tahap krusial pemenuhan hak elektoral Orang Rimba adalah pada tahap pendataan pemilih dan tahap pemungutan suara. Strategi yang dijalankan oleh KPU akan sangat menentukan. Pada bagian ini akan diuraikan bagaimana strategi KPU pada dua tahapan pemilu. Selanjutnya akan diuraikan langkah-langkah yang dijalankan oleh KPU dalam berkoordinasi dengan para pemangku kepentingan utama agar hak elektoral Orang Rimba terpenuhi.

\section{Strategi KPU pada Tahap Pendataan Pemilih}

Pendataan pemilih merupakan salah satu kegiatan yang sangat penting karenaakan menentukan siapa yang akan berhak memberikan suara dalam pemilu. Syarat untuk menjadi pemilih pada Pemilu 2019 berdasarkan Peraturan KPU (PKPU) 11/2019 adalah warga negara Indonesia yang:

1) berumur 17 tahun atau lebih pada haripemungutan suara, sudah kawin, atau sudah pernah kawin;

2) tidak sedang terganggu jiwa atau ingatannya;

3) tidak sedang dicabut hak pilihnya berdasarkan putusan pengadilan yang telah mempunyai kekuatan hukum tetap;

4) berdomisili di wilayah administratif Pemilih yang dibuktikan dengan KTP-el;

5) Jika belum memiliki KTP-el, pemilih dapat menggunakan Surat Keterangan perekaman KTPel yang dikeluarkan oleh dinas kependudukan dan catatan sipil atau instansi lain yang sejenis yang memiliki kewenangan untuk itu;
6) tidak sedang menjadi anggota Tentara Nasional Indonesia, atau Kepolisian Negara Republik Indonesia.

Berdasarkan PKPU 11/2019 terlihat bahwa KTP-el atau Surat Keterangan Perekaman KTP-el menjadi syarat untuk menjadi pemilih. Orang Rimba yang sudah menetap di dusun tidak memiliki masalah terkait syarat KTP-el ini. Orang Rimba yang tinggal di Sungai Nan Ulu, Sungai Dan Ilir, Tebing Tinggi, Padang Kelapo, dan Mersam ikut memberikan suara pada Pemilu 2019. Mereka bisa memilih karena telah memiliki KTP-el (Ali Amran, wawancara, 14 Juli 2020). Mereka dapat memiliki KTP-el karena sudah menetap sekurang-kurangnya enam bulan. Ini menunjukkan bahwa Orang Rimba kategori ketiga, yakni yang sudah menetap, telah terpenuhi hak elektoralnya.

Hal berbeda terjadi pada Orang Rimba yang masih tinggal dan hidup berpindah-pindah di hutan. Apalagi yang jarang berinteraksi dengan orang di luar hutan, syarat KTP-el ini menjadi penghambat untuk memilih. Mereka tidak memiliki KTP-el. KPU tidak bisa memasukkan mereka ke dalam DPT karena tidak memenuhi syarat. KPU juga tidak memiliki kewenangan untuk menerbitkan KTP-el atau Surat Keterangan Perekaman KTP-el karena kewenangan itu ada di Disdukcapil. Oleh karena itu, KPU Batanghari melakukan pendataan pencocokan dan penelitian (coklit) terhadap Orang Rimba sesuai dengan standar operasional prosedur (SOP) pemutakhiran daftar pemilih tetap (DPT).

Data-data tentang Orang Rimba tersebut dimasukkan ke dalam Formulir AC, yaitu formulir yang berisi data pemilih potensial non-KTP-el (Abdul Kadir, Focus Group Discussion, 7 Juli 2020). Pendataan dilakukan di dua kecamatan, yaitu Muaro Sebo Ulu dan Kecamatan Bajubang. Orang Rimba paling banyak di Kecamatan Muara Sebo Ulu, yang tersebar di tiga desa, yaitu Desa Batu Sawar, Desa Padang Kelapo, dan Desa Sungai Lingkar. Sedangkan di kecamatan Bajubang ada di desa Bungku. Orang Rimba di kecamatan Muara Sebo Ulu masih hidup berpindah-pindah. Jika ada yang meninggal akan berpindah lagi dan bisa kembali paling cepat enam bulan. Oleh karenanya, mereka tidak memiliki KTPel (Abdul Kadir, Wawancara, 13 Juli 2020). Hal itulah yang menyebabkan 588 Orang Rimba yang tinggal di hutan tidak dapat memiliki KTP-el karena syarat untuk mendapatkan KTP-el adalah menetap minimal enam bulan di suatu tempat.

\section{Strategi KPU pada Tahap Pemungutan Suara}

Meskipun 588 Orang Rimba tidak memiliki KTP-el hingga tahap penetapan DPS (daftar pemilih sementara), KPU menyiapkan tempat pemungutan 
Tindak lanjut dari koordinasi antara KPU, Disdukcapil, dan instansi terkait lainnya, Kepala Dinas, Kepala Bidang Pendaftaran penduduk, dan Kasi pendataan Disdukcapil menemui Direktur Jenderal (Dirjen) Dukcapil Kementerian Dalam Negeri (Kemendagri), Zudan Arif Fakrullah, dengan agenda meminta perubahan Peraturan Menteri Dalam Negeri (Permendagri) Nomor 11 Tahun 2010 yang menghalangi Orang Rimba bisa dapat KTP-el dan kehilangan hak politik elektoralnya pada Pemilu 2019. Upaya ini mendorong Dirjen Dukcapil menerbitkan Permendagri Nomor 96 tahun 2019 tentang Pendataan dan Penerbitan Dokumen Kependudukan bagi Penduduk Rentan Administrasi Kependudukan, untuk mengganti dan mencabut Peraturan Menteri Dalam Negeri Nomor 11 Tahun 2010 tentang Pedoman Pendataan Penerbitan Dokumen Kependudukan bagi Penduduk Rentan Administrasi Kependudukan (Ali Amran, Wawancara, 14 Juli 2020).

Perubahan aturan tersebut memungkinkan Disdukcapil bersama Kejaksaan Negeri Batanghari memfasilitasi perekaman data untuk pembuatan KTP-el dengan cara mendatangi Orang Rimba yang hidupnya berpindah-pindah. Disdukcapil Batanghari melayani perekaman data 40 Orang Rimba untuk pembuatan Kartu Keluarga, KTP, akte kelahiran dan Kartu Identitas Anak (KIA). Tanggal 2 September 2019 sebanyak 98 Orang Rimba dari kelompok Kejasung Desa Padang Kelapo, Kecamatan Muaro Sebo Ulu, Kabupaten Batangharimenerima dokumen kependudukan. Rincian dokumen kependudukan tersebut adalah 25 Kartu Keluarga, 41 KTP-el, dan 72 Akta Kelahiran (Faisal, 2019). Strategi KPU berkoordinasi dengan para pemangku kepentingan tidak berhasil pada Pemilu 2019. KPU kemudian berkoordinasi dengan Disdukcapil dan Kejaksaan Batanghari. Hasilnya adalah 41 Orang Rimba di Padang Kelapo dan Sungai Lingkar mendapatkan KTP-el pada bulan September 2019 dan dapat memberikan suara pada Pilkada Serentak 2020.

Strategi KPU Batanghari untuk memenuhi hak politik elektoral Orang Rimba dapat dikelompokkan menjadi tiga, yaitu: strategi pada tahap pendataan pemilih, strategi pada tahap pemungutan suara, dan strategi berkoordinasi dengan para pemangku kepentingan. Strategi pada tahap pendataan pemilih dilakukan dengan cara memasukkan data Orang Rimba ke dalam formulir AC. Strategi pada tahap pemungutan suara adalah menyediakan TPS khusus untuk Orang Rimba agar Orang Rimba merasa nyaman dalam memberikan suara. Hal itu dilakukan karena Orang Rimba sulit beradaptasi sebab terbiasa hidup di hutan. Sedangkan strategi berkoordinasi dengan para pemangku kepentingan dilakukan untuk menyelesaikan persoalan ketiadaan dokumen kependudukan sebagai syarat menjadi pemilih melalui kerja sama dengan Disdukcapil dan Kejaksaan Negeri Batanghari serta Dirjen Disdukcapil. Selain itu KPU Batanghari juga melakukan konsultasi dengan KPU Jambi dan KPU RI. Selain berkoordinasi dengan pemangku kepentingan yang berasal dari pemerintah, KPU Batanghari juga bekerjasama dengan pemimpin Orang Rimba, yakni 'Temenggung' dan penghubung Orang Rimba dengan orang luar, yakni 'Jenang'.

Uraian di atas menunjukkan bahwa ada perbedaansubstansidan teknisstrategiyang dilakukan oleh KPU Batanghari. Secara substansi, strategi yang dilakukan oleh KPU Batanghari adalah upaya untuk memenuhi hak politik elektoral kelompok minoritas adat terpencil, yakni Suku Anak Dalam, sub-etnis Orang Rimba. Sedangkan strategi yang dilakukan oleh KPU Kabupaten Bone adalah untuk memenuhi hak politik penyandang disabilitas (Akmal, 2019). Sementara strategi yang dilakukan oleh KPU Kabupaten Magelang dalam rangka meningkatkan partisipasi politik kelompok minoritas berdasarkan gender, yakni kelompok minoritas perempuan (Wibowo et al., 2019). Secara teknis, strategi KPU Kabupaten Bone adalah untuk memenuhi hak politik penyandang disabilitas dilakukan sesuai dengan peraturan perundangan yang berlaku. Sedangkan teknis yang dilakukan oleh KPU Magelang dalam meningkatkan partisipasi perempuan adalah secara offensive dan defensive secara bersamaan, dengan pendekatan ofensif yang lebih dominan. Selain itu sosialisasi dilakukan dengan pendekatan formal, informal, dan melalui media massa.

Hasil penelitian juga menunjukkan bahwa KPU Batanghari memiliki komitmen terhadap pemenuhan hak politik elektoral Orang Rimba dengan melakukan tiga strategi di atas. Namun strategi KPU tidak berhasil pada Pemilu 2019 dan berasil pada pemilihan berikutnya, yakni Pilkada serentak 2020, 41 Orang Rimba mendapatkan hak pilih elektoralnya. KPU Batanghari menghadapi beberapa kendala, seperti keterbatasan wewenang yang dimiliki oleh KPU. KPU hanya membuat data pemilih sedangkan syarat untuk menjadi pemilih, berupa KTP-el, merupakan wewenang Disdukcapil. Perspektif KPU dan semua pemangku kepentingan yang berasal dari pemerintah yang memperlakukan Orang Rimba sama dengan warga lainnya yang tidak hidup di hutan membuat pemenuhan hak elektoral terhambat. Untuk menyelesaikan kendala dalam rangka memenuhi hak politik elektoral, pemerintah perlu mempertimbangkan penggunaan Sistem Noken, sebagaimana yang diberlakukan terhadap etnis Papua yang tinggal di kawasan Pegunungan Tengah Papua. 


\section{SIMPULAN}

Uraian pada bagian-bagian sebelumnya telah men-jelaskan bahwa faktor penyebab Orang Rimba tidak mendapatkan KTP-el adalah karena cara hidup Orang Rimba yang berpindah-pindah, keyakinan yang dimiliki oleh Orang Rimba, dan tidak adanya aturan khusus untuk Orang Rimba yang memiliki kebudayaan berbeda dengan orang yang hidup menetap. Sedangkan, strategi KPU Batanghari untuk memenuhi hak politik elektoral Orang Rimba dapat dikelompokkan menjadi tiga, yaitu: strategi pada tahap pendataan pemilih, strategi pada tahap pemungutan suara, dan strategi berkoordinasi dengan para pemangku kepentingan. Strategi pada tahap pendataan pemilih dilakukan dengan cara memasukkan data Orang Rimba ke dalam formulir AC. Strategi pada tahap pemungutan suara adalah menyediakan TPS khusus untuk Orang Rimba agar Orang Rimba merasa nyaman dalam memberikan suara. Hal ini dilakukan karena Orang Rimba sulit beradaptasi, sebab mereka terbiasa hidup di hutan. Sedangkan strategi berkoordinasi dengan para pemangku kepentingan dilakukan untuk menyelesaikan persoalan ketiadaan dokumen kependudukan sebagai syarat menjadi pemilih melalui kerja sama dengan Disdukcapil dan Kejaksaan Negeri Batanghari serta Dirjen Disdukcapil. Selain itu KPU Kabupaten Batanghari juga melakukan konsultasi dengan KPU Provinsi Jambi dan KPU RI. Selain berkoordinasi dengan pemangku kepentingan yang berasal dari pemerintah, KPU Kabupaten Batanghari juga bekerjasama dengan pemimpin Orang Rimba, yakni 'Temenggung' dan penghubung Orang Rimba dengan orang luar, yakni 'Jenang'.

Temuan dari penelitian ini menunjukkan bahwa strategi KPU untuk memenuhi hak politik elektoral Orang Rimba telah mempertimbangkan kewenangan KPU dan telah memperhatikan kondisi khusus yang dimiliki oleh Orang Rimba. Namun demikian, strategi perlu ditingkatkan ke dalam aspek yang bersifat politis, tidak berhenti pada aspek politik berupa kewenangan. Oleh karena itu perlu kebijakan affirmative action bagi Orang Rimba, berupa pengecualian cara memberikan suara. Jika pada warga yang telah menetap satu warga memberikan suara secara langsung, umum, bebas, dan rahasia, tetapi Orang Rimba yang hidup berbeda dan tempat tinggalnya di dalam hutan dapat mewakilkan dengan memberikan suara melalui pemimpin adatnya.

Keterbatasan penelitian ini adalah tidak dapat bertemu langsung dengan Orang Rimba yang tinggal di hutan. Orang Rimba sangat membatasi orang luar untuk masuk ke wilayah tempat tinggalnya. Situasi di sekitar tempat tinggal Orang Rimba di Batanghari juga sedang tidak aman karena persoalan kriminal.
Selain itu, penyebaran pandemi Covid-19 membatasi pergerakan peneliti sekaligus membuat Orang Rimba semakin tidak mau bertemu dengan orang luar karena adanya kepercayaan bahwa orang luar membawa penyakit. Mengingat keterbatasan ini, penelitian hanya membahas hak politik elektoral. Karena itu, perlu penelitian lebih lanjut tentang Orang Rimba yang tinggal di hutan untuk menginventarisasi persoalan-persoalan pemenuhan HAM Orang Rimba di luar pemilu.

\section{UCAPAN TERIMA KASIH}

Terima kepada Lembaga Penelitian dan Pengabdian kepada Masyarakat (LPPM) Universitas Lampung (Unila) atas Hibah Penelitian Pascasarjana Unila, Nomor 1427/UN26.21/PN/2020, Tanggal 24 Maret 2020, yang telah menghasilkan tulisan ini.

\section{DAFTAR PUSTAKA}

Akmal, A. (2019). Peran Komisi Pemilihan Umum (KPU) Kabupaten Bone dalam Pemenuhan Hak Politik Penyandang Disabilitas di Pemilihan Umum Tahun 2019. Jurnal AlDustur, 2(2), 137-160.

Ali, A. (2004). The Muslims of Sri Lanka: an Ethnic MinorityTrappedinaPoliticalQuagmire.InterAsia Cultural Studies, 5(3), 372-383. https:// doi.org/10.1080/1464937042000288679

Budiardjo, M. (2008). Dasar-dasar Ilmu Politik. Gramedia.

Bye, V., \& Ostebo, P. (2020). Literature Review Democracy and Human Rights in Contemporary Latin America (2015-2020). Trends, Challenges, and Prospects. CMI.

Catt, H. (2014). Electoral Management Design (Revised Ed). International Institute for Democracy and Electoral Assistance.

Faisal, A. (2019). Sebanyak 98 Suku Anak dalam Batanghari dapat KTP. Gatra.Com.

Firmansyah, M. (2019). Komnas HAM: Ribuan Pemilih Terancam Tak Bisa Mencoblos. Alinea.Id.

Franklin, M.N. (2002). The Dynamics of Electoral Participation. In L. Laurence, R. Niemi, \& P. Norris (Eds.), Comparing democracies (Vol. 2, pp. 148-168). Sage Publications.

Gizachew, G.W. (2019). Minority and Federalism: an Assessment of the Right to Political Participation of 'Non-indigenous' Peoples in Benishangul-Gumuz Regional State, Ethiopia. International Journal of Human Right and Constitutional Studies, 6(3), 192-213. https:// doi.org/10.1504/JJHRCS.2019.097963 
Juaini, A. (2020). Dokumen Pribadi. KPU Kabupaten Merangin.

KKI WARSI. (2019). Tetapkan Hutan Adat Setelah Dikukuhkan Bupati. Bulatin Alam Sumatera, 19-23.

KKI WARSI. (2020). Orang Rimba, Kubu, dan Suku Anak Dalam (SAD). KKI WARSI.

Lawoti, M. (2007). Political Exclusion and the Lack of Democratisation: Cross-National Evaluation of Nepali Institutions using a MajoritarianConsensus Framework. Commonwealth \& Comparative Politics, 45(1), 57-77. https:// doi.org/10.1080/14662040601135755

Miles, M.B., \& Huberman, A.M. (1992). Analisis Data Kualitatif (T.R. Rohidi (ed.); Terjemahan). UI Press.

Mulyani, W., \& Parapat, J.H. (2018). Demografi Orang Rimba/Suku Anak Dalam TNBD (W. Mulyani (ed.)). Balai Taman Nasional Bukit Duabelas.

Prasetijo, A. (2011). Serah Jajah dan Perlawanan yang Tersisa - Etnografi Orang Rimba di Jambi. Wedatama Widya Sastra.

Prastiwi, D. (2018). Tak Punya KTP, Suku Anak Dalam Batanghari Kehilangan Hak Pilih di Pemilu 2019. Liputan6.Com.

Qodir,Z. (2014). Hak Politik Kaum Minoritas Towani Tolotang di Sulawesi Selatan. UNISIA, 36(8), 179-197.

Rahman, D.A. (2019). Komnas HAM Tekankan Prinsip Kesetaraan bagi Pemilih Pemilu 2019. Kompas.Com.

Rahmatunnisa, M. (2016). Affirmative Action dan Penguatan Partisipasi Politik Kaum Perempuan. Jurnal Wacana Politik, 1(2), 9095. https://doi.org/10.24198/jwp.v1i2.11049

Rasyidi, A.F. (2017). Implikasi Pengabaian Hak Sipil dan Politik Masyarakat Moro-Moro dalam Pemilihan Kepala Daerah. Jurnal HAM, 8(1), 39-50. https://doi.org/10.30641/ ham.2017.8.39-50

Richards, P. \& Gardner, J.A. (2013). Still Seeking Recognition: Mapuche Demands, State Violence, and Discrimination in Democratic Chile. Latin American and Caribbean Ethnic Studies, 8(3), 255-279. https://doi.org/DOI: 10.1080/17442222.2013.779063
Robinson, K. (2019). Can Formalisation of Adat Land Regulation Protect Community Rights? The Case of the Orang Asli Sorowako and the Karongsi'e/Dongi. The Asia Pacific Journal of Anthropology, 20(5), 471-486.

Sakbani, Y. (2020). Urgensi Manajemen Risiko Pemilu pada Pilkada 2020 di Tengah Pandemi Covid-19 (Studi Perlindungan Hak Pilih Warga Masyarakat). Jurnal Wacana Politik, 5(2), 124-135.

Stoke, K. (2017). Politics of Citizenship: Toward an Analytical Framework. In E. Hiariej \& K. Stoke (Eds.), Politics of Citizenship in Indonesia (pp. 26-27). Yayasan Obor Indonesia.

Suparlan, P. (2011). Kata Pengantar. In A. Prasetijo (Ed.), Serah Jajah dan Perlawanan yang Tersisa, Etnografi Orang Rimba di Jambi (p. ix). Wedatama Widya Sastra.

Syaputra, M.Y.A. \& Nasution, M.(2019). Pemenuhan Hak Konstitusional Masyarakat Penganut Kepercayaan Lokal dalam Pemilihan Umum. Jurnal Yuridis, 6(1), 46-66.

Wee, V. (2002). Ethno-nationalism in process: Ethnicity, Atavism and Indigenism in Riau, Indonesia. The Pacific Review, 15(4), 497-516. https://doi. org/10.1080/0951274021000029396

Wibowo, E.A., Muradi, \& Sudirman, A. (2019). Strategi Sosialisasi Politik dalam Peningkatan Partisipasi Pemilih Perempuan pada Pilkada Serentak di Kota Magelang. Jurnal Ilmu Pemerintahan Cosmogov, Vol 5(No. 1), 2244.

Yaacob, M.R., \& Woong, L. (2007). Stakeholders' Activisms: Indigenous Peoples' of Sarawak Resistance against the State Government and Corporations. Social Responsibility Journal, 3(2), 39-51. https:/doi. org/10.1108/17471110710829713

Yin, R.K. (1994). Case Study Research, Design and Method (Second Edition). Sage Publications.

Zulkarnain, I., Soetarto, E., Sunito, S., \& Adiwibowo, S. (2018). Pembungkaman Suara Politik Pengakuan Masyarakat Adat dalam Perspektif Ekonomi Politik (Studi kasus di Suku Mapur Lom Bangka Belitung. Sodality: Jurnal Sosiologi Pendesaan, 6(3), 237-245. 